Aletria, Belo Horizonte, v. 30, n. 4, p. 43-64, 2020

(c) (i)

\title{
Traduzir-se po-eticamente
}

\section{Translating Oneself Po-ethically}

\author{
Alice Maria Araújo Ferreira \\ Universidade de Brasília (UnB), Brasília, Distrito Federal / Brasil \\ malice4869@gmail.com \\ https://orcid.org/0000-0003-4113-1173
}

Resumo: Neste ensaio, propomos discutir as questões éticas implicadas na relação tradutória, mais particularmente na chamada "versão", ou seja, no traduzir-se para/no outro. Assim, propomos, primeiramente, revisitar uma certa tradição discursiva sobre as questões éticas do traduzir a partir da "virada ética" da Prova do estrangeiro (1984), de Antoine Berman, e seus desdobramentos em autores como Anthony Pym (1997), Lawrence Venuti (1993), Mona Baker (2019), Gayatri Spivak (1993, 2005) e Henri Meschonnic (2007). Em seguida, fazemos uma distinção entre as noções de estrangeiro e e/i-migrante para pensar uma prova do e/i-migrante no movimento do traduzir-se. Para distinguir o traduzir do traduzir-se, convocamos as questões da direcionalidade e da afetividade no/do sujeito-tradutor. Enfim, pensar uma relação ética do traduzirse no/com/para o outro, do sair de si, afetar-se com/pelo outro, voltar a si e afetar o outro, comparece, no nosso ensaio, no ethos do e/i-migrante como paradigma desse movimento.

Palavras-chave: relação ética; traduzir-se; e/imigrante; versão.

Abstract: In this essay, we propose discussing the ethical issues involved in the translation relationship, particularly in the so-called version, that is, when translating one-self to/in the other. Thus, we propose, first of all, revisiting a specific discursive tradition on translation's ethical issues, stemming from Antoine Berman's "ethical turning point" in The Experience of the Foreign, and its developments in authors such as Anthony Pym (1997), Lawrence Venuti (1993), Mona Baker (2019), Gayatri Spivak (1993, 2005), and Henri Meschonnic (2007). Afterwards, we make a distinction between the notions of foreigner and e/i(m)-migrant, in order to think about the experience of 
$\mathrm{e} / \mathrm{i}(\mathrm{m})$-migrant in the action of translating oneself. In order to distinguish between translating and translating oneself, we address directionality and affectivity issues in/of the translator-subject. In short, to think of an ethical relationship of translating oneself in/with/for the other, of getting out of oneself, affecting oneself with/by the other, getting back to oneself and affecting the other, is presented in our essay in the ethos of the e/i(m)-migrant as this action's paradigm.

Keywords: ethical relationship; translating oneself; e/i(m)-migrant; version.

L'utopie du projet, de cette pensée même d'une telle interaction, impose une nécessité de l'humour contre tout le pseudo-sérieux qui confond les Assis avec le mouvement de la pensée.

Henri Meschonnic. Éthique et politique du traduire, 2007, p. 9

A ética e a estética são uma só.

Ludwig Wittgenstein. Tractatus Logico-philosophicus, 1994, p. 421.

\section{Introdução}

A concepção de tradução como relação tem levado vários estudiosos a discuti-la nos mais diversos âmbitos (entre, com, para); e nas mais diversas instâncias (línguas, culturas, literaturas, sujeitos, convenções sociais). No âmbito epistemológico, discutir relações levanta questões políticas, poéticas e éticas que não se separam tão facilmente.

Neste ensaio, propomos discutir as questões éticas implicadas na relação tradutória, mais particularmente na versão, ou seja, quando nos traduzimos para/no outro.

A palavra ética surgiu do grego ethos e aparecia principalmente como adjetivo. Tratava-se de saber se uma ação, um comportamento, uma qualidade, um modo de ser eram ou não éticos. $\mathrm{O}$ adjetivo se ligava às virtudes práticas para a realização da vida do estado, como a justiça, a amizade, o valor, ou então às virtudes como a sabedoria e a prudência. Pensar a partir do adjetivo o traduzir-se é discutir sobretudo um modo de ser em relação, ou melhor, um modo de (rel)ação com/para outro, e mobilizou discursos sobre amizade em Montaigne e Derrida, justiça em Kant e afecções em Spinoza, Deleuze, Guattari e Safatle por exemplo. Depois da Grécia Antiga (e por causa dela), a ética foi pouco a pouco 
associada às questões morais, tornando-se uma disciplina filosófica, uma ciência, um substantivo. O que propomos discutir é da ordem de uma qualidade, um comportamento, um modo de ser de/em relação, que conceitualmente se traduzem mais por adjetivos, advérbios e preposições.

A história do pensamento sobre a relação ética pode ser encontrada tanto na filosofia moral e na deontologia quanto na sociologia, na antropologia, nos estudos da linguagem, na tradução, ou seja, concerne a todas/os.

Para distinguir o traduzir do traduzir-se e o que isso implica nas relações éticas, partimos de uma certa tradição discursiva bermaniana e seus desdobramentos em Anthony Pym (1997) e Lawrence Venuti (1998), nas leituras de Barbara Godard (2001) e Henri Meschonnic (2007). No processo, a pronominalização do traduzir-se convoca as questões de direcionalidade e afetividade envolvidas nas relações com/para/em. Enfim, pensar uma relação ética do traduzir-se no outro, de sair de si, afetar-se com/pelo outro, voltar a si e afetar o outro, comparece, no nosso ensaio, no ethos do e/imigrante como relação/metáfora desse movimento.

\section{Uma certa tradição discursiva sobre a ética da tradução, do traduzir, do tradutor}

Segundo Tiphaine Samoyault (2020, p. 224, tradução nossa), teríamos três perspectivas principais de discursos sobre a ética do traduzir:

(...) uma que passa pelas línguas e o dialogismo (de base francesa e alemã), outra que passa pelos sujeitos (de base francesa também), e aquela que passa pelas culturas (de base anglo-saxã, mesmo se inspirada em uma leitura da teoria francesa). ${ }^{1}$

Nelas, a questão ética passa sempre pela relação com o outro e a alteridade, mas não do mesmo modo em função da visada, filosófica ou pragmática. Para a autora, o desenvolvimento dessa virada ética nos estudos da tradução mobilizou discursos sobre a relação das línguas entre elas e a consideração do próprio traduzir como relação, diálogo,

\footnotetext{
${ }^{1}$ « (...) l'une qui passe par les langues et le dialogisme (plutôt de base française et allemande), l'autre qui passe par les sujets (plutôt de base française également) et celle qui passe par les cultures (plutôt de base anglo-saxonne, même si elle peut s'inspirer d'une certaine lecture de la théorie française). »
} 
encontro. $\mathrm{O}$ ato fundador dessa virada estaria em $L$ 'Épreuve de l'étranger [A prova do estrangeiro] de Antoine Berman (1984): "É o ato fundador proposto por Antoine Berman em A prova do estrangeiro em 1984, que reconhece a luta que travam as línguas na tradução, o forçar da língua materna pela língua do outro e que convida a fazer da tradução o lugar onde se expõe a diferença" (BERMAN, 1984, p. 16, tradução nossa). ${ }^{2}$

Posição já apontada por Barbara Godard (2001, p. 55, tradução nossa), para quem L'Épreuve de l'étranger (1984) inauguraria uma "virada ética" ao se propor pensar o traduzir no âmbito das relações interculturais e pautado no reconhecimento do outro:

Poderíamos inscrever a transformação das teorias da tradução sob o signo de uma "virada ética" que teria sido inaugurada em 1984 com a publicação de $A$ Prova do estrangeiro, pois Antoine Berman, também, privilegiou as relações interculturais com o outro. [...]. Ele articula "a visada ética do traduzir" em termos de reconhecimento "do outro". ${ }^{3}$

No entanto, ela modaliza seu discurso, com o uso do conditionnel [futuro do pretérito] que questiona, de alguma maneira, até onde se deu essa "virada ética" nas práticas e teorias da tradução. A questão ética se instaura como visada, horizonte do fazer que se daria na relação com o outro, uma relação de reconhecimento e abertura. O outro é o estrangeiro que nos põe à prova ao traduzi-lo, pondo à prova nossa relação ética, nosso comportamento ao ser afetado por/com ele.

A Prova do estrangeiro (1984) inaugura uma virada ética nos discursos sobre a tradução, privilegiando o reconhecer (subjetivação) contra o conhecer (objetivação) nas relações interculturais, interlinguísticas e internacionais. Lembramos da citação mais famosa de Berman (1984, p.16): "A essência da tradução é de ser abertura, diálogo, mestiçagem,

\footnotetext{
2 « C'est l'acte fondateur posé par Antoine Berman avec L'Épreuve de l'étranger en 1984, qui reconnaît la lutte que se livrent les langues dans la traduction, le forçage de la langue maternelle par la langue de l'autre et qui invite à faire de la traduction le lieu où s'expose cette différence. »

${ }^{3}$ « On aurait pu inscrire la transformation des théories de la traduction sous le signe d'un ' virage éthique ' qui aurait été inauguré en 1984 avec la publication de L'Épreuve de l'étranger, car Antoine Berman a privilégié lui aussi les rapports interculturels avec l'autre. »
} 
descentramento. Ela põe em relação, ou não é nada". ${ }^{4}$ A questão ética convocada no traduzir recai mais na relação que promove do que pelo transporte que operaria. Para Berman (1984), a tradução é inseparável das questões éticas, sociais e políticas, e isso, na França pós-colonial dos anos 80, se torna um engajamento crítico para pensar a abertura e a convivialidade da cultura francesa etnocêntrica, ou melhor, na qual o etnocentrismo se escancara com a chegada de imigrantes, repatriados e exilados do mundo inteiro em especial das ex-colônias. A relação ética, na qual o próprio é transformado pela mediação do outro, enfrenta resistências profundas nas estruturas etnocêntricas de uma sociedade que busca, a todo custo, conservar sua tradição hegemônica numa volta a si, a uma identidade nacional.

A "virada ética" em tradução para Berman $(1984,2007)$ é pautada pelo acolher (albergue), pelo respeito à diferença, pelo diálogo, pela mestiçagem, e se desenvolve em meio aos discursos sobre a imigração e o acolhimento aos estrangeiros (não-franceses) na França do início dos anos 80 .

A França pós-colonial iniciada nos anos 60 (após a Guerra de independência da Argélia e Guerra Fria) vai ver chegar "estrangeiros" de muitos lugares: cidadãos ultramarinos (colonos - pieds-noirs [pés negros]) e nativos das ex-colônias (argelinos, marroquinos, tunisianos...), trabalhadores fugindo de ditaduras e guerras civis herdadas dos anos 30 (portugueses, italianos, espanhóis...), além de exilados de ditaduras da América Latina. A diversidade vivida no seu território abala uma coerência nacional (que podem chamar de identidade) transformando a paisagem das grandes cidades com banlieues, periferias marginalizadas habitadas doravante por trabalhadores para a indústria, a construção civil, e os serviços domésticos que trazem, nos corpos e nos dizeres, histórias, costumes, religiões outras. A relação com o estrangeiro se instaura nos discursos político-filosóficos (logo, éticos) e se torna rapidamente (pela complexidade da questão) uma verdadeira épreuve [prova], um desafio sociopolítico e filosófico para o país de Montaigne, Montesquieu e Voltaire; o país da Revolução, da Declaração universal dos direitos do homem, para o país de Liberté, Égalité, Fraternité. Entre os discursos, estão o da France terre d'accueil [França terra de acolhimento], o da

\footnotetext{
${ }^{4}$ « L'essence de la traduction est d'être ouverture, dialogue, métissage, décentrement. Elle est mise en rapport, ou elle n'est rien »
} 
abertura ao estrangeiro, o da diferença e da tolerância, o da mestiçagem e da France Plurielle [França Plural]. Esses se mobilizam frente aos discursos nacionalistas e racistas da La France aux Français [A França para os franceses] do Front National [Frente Nacional] (que retoma o lema da independência argelina Algérie aux Algériens [AArgélia para os argelinos], num uso perverso, comparando a ocupação colonial francesa à chegada dos argelinos à França), que fomentam terror e medo do diferente.

Nos anos 80, a transformação social criada pela presença dos estrangeiros, que a essa altura já são imigrantes e compõem o tecido social, é vista como ameaça à coesão nacional e causa dos problemas econômicos e sociais que começam a se desenhar dando espaço a políticas nacionalistas e neoliberais. Por outro lado, os discursos de respeito à diferença e do acolhimento, que tentam transformar o espírito de resistência que se articulava na França até então contra a ocupação/ invasão alemã (Front Populaire [Frente Popular]), chegam, no máximo, a uma condescendência (pois a desconstrução é difícil). Berman fala nos anos 80 de ouverture [abertura] ao estrangeiro para uma revitalização das convenções sociais. Mas, mesmo com a mudança histórica (França pós-Segunda Guerra para França pós-colonial), a chegada do outro é ainda vista/ressentida como ameaça, e resistir é não se perder ou perder sua identidade nacional e/ou não perder sua posição de poder.

Ao formular uma crítica e uma analítica da tradução, Berman (1984, 2007) visa estabelecer uma relação dialógica entre a língua materna e a língua estrangeira que põe em jogo uma visada ética pautada no reconhecimento do outro como outro, que, segundo Berman (2007), se realiza na tradução da letra, o mais perto possível do jogo de significantes. Essa proposta desloca a discussão sobre a tradução da oposição tradicional entre sentido e forma, para uma educação ao estrangeiro perturbador e revitalizante. No entanto, como vamos ver, aos poucos, ele desloca a questão pautada na crítica à tradução etnocêntrica, para uma discussão sobre um absoluto ético em tradução.

Em Pour une critique des traductions (1995) [Para uma crítica das traduções], o caráter ético baseado no reconhecimento do outro enquanto tal enfrenta resistências, já que não submeter o outro a nenhuma restrição local pode levar à possível desagregação do que se constitui como identidade (do local). Estamos diante de uma relação ética quase impossível, que negocia a acolhida do outro e a transformação do mesmo 
sem que nenhum (nem o outro nem o mesmo) se desconstrua. Assim, Berman (1995) passa a discutir um absoluto ético da tradução, em que a tradução deixa de ser ética quando é feita num ambiente de in-verdade. A ética do reconhecimento do outro, do acolhimento dá lugar a uma pure visée traduisante [pura visada traduzinte] que vai se opor à "ética da diferença" e a uma política da tradução nas teorias de Henri Meschonnic (1999; 2007), Lawrence Venuti (1993) e Gayatri Spivak (1993; 2005).

Leitor de Jacques Derrida, Berman (2007) retoma seu conceito de língua como hospitalidade: "o convite, a acolhida, o asilo, o albergamento passam pela língua ou pelo endereçamento ao outro. [...] a língua é hospitalidade" (DERRIDA, 1997, p. 119, tradução nossa, grifo do original $)^{5}$ e com o fato que se fechar ao estrangeiro é se fechar à revitalização da cultura de recepção. A decisão ética passaria pela acolhida do outro e pela revitalização do mesmo. Mas, quando para Derrida, é preciso acolher o outro em sua radical diferença, ou seja, para que o outro seja de fato outro e não uma projeção narcísica e/ou egoica do mesmo, é preciso aceitar que as normas da casa sejam dele e não mais do anfitrião, Berman (2007) acolhe o estrangeiro num albergue, não numa casa. Se o conceito de estrangeiro é caro ao Romantismo alemão do século XIX, no/do qual Berman (1984) se alimenta, o tema da imigração ainda é constrangedor.

Anthony Pym (1997, p. 9), para quem a discussão de Berman (1984) é "acadêmica demais, intelectual demais, abstrata demais"' (quase política demais), desloca a questão ética para o sujeito e propõe uma ética profissional do tradutor. Ele concebe a tradução não só como ato de comunicação (PYM, 1997, p. 10), mas como transação econômica, "um serviço profissional com um cliente para um receptor determinado". 7 A relação ética que apresenta é socioeconômica e a atenção é dada à recepção. Para Pym (1997), se há uma relação ética do tradutor, ela se dá com seu cliente e não com o estrangeiro, a alteridade ou o original. Nesse sentido, a questão da direcionalidade, ou seja, se o estrangeiro é fonte ou alvo, não é questão nem problema. O fazer do tradutor é guiado por diferentes ordens: as recomendações dos clientes, as normas

\footnotetext{
${ }^{5}$ « (...) l'invitation, l'accueil, l'asile, l'hébergement passent par la langue ou par l'adresse à l'autre. [...] la langue est hospitalité. »

$6 \ll(. .$.$) trop académique, trop intelectuelle, trop abstraite. »$

7 «(...) un service professionnel auprès d'un client pour un récepteur donné. »
} 
aplicadas à tradução, os prazos, as distâncias. O fazer ético se baseia na responsabilidade do profissional e busca favorecer a relação entre o tradutor e seu cliente. Pym (1997) apresenta princípios éticos que se parecem mais a um código de deontologia no qual todo profissional deve se apoiar para tomar decisões. O profissional, segundo ele, precisa que "a ética seja capaz de sustentar decisões mesmo que sejam complexas e práticas [...] quem paga? Para que serviço? E quanto?" (PYM, 1997, p. 11 , tradução nossa). ${ }^{8}$

Essa responsabilidade ética do profissional preconizada por Pym garantiria ao cliente a não intervenção do tradutor nos produtos (as traduções) e por isso pressuporia o apagamento do fazer tradutório, ou, como diz Mona Baker em uma entrevista concedida recentemente a Junia Zaidan:

O compromisso com a não intervenção, em especial, é considerado necessário como garantia aos clientes e ao público de que podem confiar que os tradutores e intérpretes não deixarão qualquer vestígio de suas próprias visões ou ideologias nos textos que produzem, não contaminarão a mensagem que o emissor "tem em mente (BAKER, 2019, p. 16).

$\mathrm{E}$, mais à frente, alerta como a lógica do mercado contamina a formação de tradutores e intérpretes, pois focalizar apenas na relação com o cliente não contribui para a formação de tradutores como cidadãos responsáveis pela construção de um mundo menos desigual:

Mesmo em relação à formação de futuros tradutores e intérpretes profissionais, não faz sentido e tampouco é realista focalizar apenas as necessidades e preconceitos de clientes potenciais e ignorar as responsabilidades éticas e sociais de tradutores e intérpretes como cidadãos que participam ativamente da produção de todos os aspectos do ambiente em que vivemos. (BAKER, 2019, p. 16)

O que está em jogo, em Pym (1997), é uma deontologia pautada na lógica de mercado, e consequentemente, ele se afasta das questões éticas e políticas envolvidas no processo tradutório. Para Henri Meschonnic

\footnotetext{
${ }^{8}$ «(...) l'éthique soit capable de soutenir des décisions aussi complexes et pratiques soient-elles. [...] qui paie ? pour quel service ? Et combien ?.»
} 
(2007, p. 15), o que resta da reflexão de Pym é um comportamento ético baseado no critério comercial, e talvez, uma reflexão sobre as "estratégias"; "e, se formos assaz laxistas para rebaixar a isso a noção de ética, uma 'ética de cooperação' (PYM, 1997, p. 133). Mas não uma ética do traduzir. É uma redução ao mercado". ${ }^{9}$

Para Meschonnic (2007), a questão ética do traduzir passa pelos sujeitos, mas por sujeitos que agem. Em Éthique et politique du traduire [Ética e política do traduzir] (2007), ele nos propõe pensar o traduzir como um agir po-ético (político e ético). A tradução passa a ser um espaço de encontro no qual os sujeitos podem tornar-se sujeitos. Para ele, a relação ética:

Não como uma responsabilidade social, mas como a busca de um sujeito que se esforça em se constituir como sujeito pela sua atividade, mas uma atividade tal que só é sujeito aquele por quem um outro é sujeito. E nesse sentido, como être de langage [ser de linguagem], esse sujeito é inseparavelmente ético e poético. É na medida dessa solidariedade que a ética da linguagem concerne todos os seres de linguagem, cidadãos da humanidade, e é nesse sentido que a ética é política (MESCHONNIC, 2007, p. 8). ${ }^{10}$

Ele nos convida a pensar a tradução como um agir simultâneo entre dois sujeitos e pelo qual ambos surgem como sujeitos. Assim, é o sujeito do texto que faz do tradutor um sujeito traduzinte; são inseparáveis e implicam uma igualdade e reciprocidade (ética e poética). Nessa perspectiva as categorias da comunicação (receptor, emissor, fonte, alvo) se tornam inoperantes porque a visada é a relação, o discurso. $\mathrm{Ou}$ seja, a linguagem habitada por um sujeito/corpo que não pode/deve ser traduzido por uma língua, mas por outro discurso. Pensar a relação ética

\footnotetext{
${ }^{9}$ « (...) et, si on est assez laxiste pour y rabaisser la notion d'éthique, une "éthique de coopération" (Pym, 133). Mais pas une éthique du traduire. C'est une réduction au marché. »

${ }^{10}$ « (...) [N]on comme une responsabilité sociale, mais comme la recherche d'un sujet qui s'efforce de se constituer comme sujet par son activité, mais une activité telle qu'est sujet celui par qui un autre est sujet. Et en ce sens, comme être de langage, ce sujet est inséparablement éthique et poétique. C'est dans la mesure de cette solidarité que l'éthique du langage concerne tous les êtres de langage, citoyens de l'humanité, et c'est en quoi l'éthique est politique. »
} 
fora da política é desconsiderar os sujeitos instaurados po-eticamente na linguagem ("être de langage") como corpos políticos.

Lawrence Venuti, em The Scandals of Translation: Towards an ethics of difference (1998) [Os Escândalos da Tradução: para uma ética da diferença], pensa a tradução não mais como serviço ou ato de assimilação, mas como reconhecimento da diferença interlinguística e intercultural, um ato político transformador (um escândalo). Ele nos propõe uma "ética da diferença" e da posição, "Ethics of location" [ética da posição ou localização]. Se a diferença se manifesta na relação (comparação, analogia), há posições na relação e cada lado desenvolve po-eticamente estratégias de resistências e aberturas. Considerar a posição do tradutor nas discussões sobre um traduzir ético passa por uma (rel) ação crítica e criativa do tradutor com o outro. Assim, para Venuti (1998), a estranheza mantida numa tradução, por exemplo, não deriva apenas de uma postura ética em relação ao estrangeiro e à letra, ela deriva tanto de forças estratégicas da cultura-fonte quanto da cultura-alvo, em função das relações de poder que se exercem entre elas. Na cultura-alvo, os rastros (todas as significações pelas quais passaram os signos) criam resistências. Em ambas (cultura-fonte e alvo), histórias de resistências afetam suas posições tradutórias. Não só as posições tradutórias clássicas, fonte/alvo, forma/conteúdo, mas posições/oposições geopolíticas historicamente constituídas entre colonizador/colonizado; homem/mulher; branco/preto; homossexual/heterossexual; nacional/estrangeiro.

Se a "ética da diferença" preconizada por Venuti expõe os valores e as práticas da cultura de acolhimento para perturbar e transformar a formação identitária, e assim se tornar um "escândalo" (VENUTI, 1998, p. 82), a "ethics of location" [ética da posição ou localização] mostra de que modo a prática tradutória participa da manutenção da hegemonia em escala global, na qual as línguas são hierarquizadas política e economicamente, produzindo valores assimétricos entre as culturas. Venuti pensa uma postura ética no confronto com as desigualdades sóciohistóricas. As desigualdades produzidas ao longo da história colonial e pós-colonial não são meros fatores que a tradução tem que reproduzir (por coerções econômicas e políticas); ao contrário, o ato tradutório que põe em relação deve se esforçar para quebrá-las. $\mathrm{O}$ ato tradutório ético torna-se uma forma de transformação não só linguística, mas social. Nesse sentido, para Godard, Venuti (1998) se aproxima mais de 
uma perspectiva nietzschiana de crítica às estruturas de poder, do que propriamente bermaniana:

Numa tal ótica nietzschiana, Lawrence Venuti compreende o chamado de Antoine Berman como "uma prova do estrangeiro" por onde a tradução tornar-se-ia uma forma crítica das estruturas escondidas do poder para empreender uma verdadeira transvaloração. Proclamando-se herdeiro do projeto bermaniano, Venuti se alinha, todavia, com seu subtítulo, mais do lado de Nietzsche. ${ }^{11}$ (GODART, 2001, p. 72, tradução nossa)

Venuti (1998) examina como a tradução "etnocêntrica" que Berman (2007) critica funciona como estratégia discursiva dos agentes sociais (editores e outros) para manter a hegemonia de uma língua e reforçar poderes econômicos, e mostra como nos países não-hegemônicos a tradução de obras estrangeiras não tem o mesmo valor. Nesse sentido, sabemos que a tradução varia em função de uma economia/mercado das línguas e os valores da tradução etnocêntrica e da tradução ética (e o que constitui essas categorias) mudam frente às contingências sóciohistóricas localizadas (VENUTI, 1998, p. 197). As mudanças de normas nas relações entre as pessoas e entre as nações conduzem a reformulações radicais nos discursos sobre as traduções e o traduzir eticamente.

Reencontramos a questão da posição/localização em Gayatri Spivak (1993) para quem a tradução não pode ser vista como uma simples manipulação interlinguística, mas como relação entre culturas que produz uma "transvalorização cultural" na qual o reconhecimento do outro pode reiterar ou perturbar as relações de poder. Spivak (1993), ao propor uma "ética da diferença cultural", exige um reconhecimento do outro enquanto outro para transformar as relações hegemônicas construídas pelo imperialismo entre as culturas europeias e estadunidenses e as culturas do chamado terceiro mundo. Desse modo, podemos dizer que Spivak (1993) defende, como Venuti (1998), uma postura ética ligada à situação discursiva, já que a violência política que existe na tradução manifesta as relações assimétricas entre línguas e nações. Para Spivak

${ }^{11}$ «C'est dans une telle optique nietzschéenne que Lawrence Venuti comprend l'appel d'Antoine Berman comme ' une épreuve de l'étranger' par où la traduction deviendrait une forme de critique des structures cachées du pouvoir afin d'entreprendre une véritable transvaluation. Se proclamant l'héritier du projet bermanien, Venuti s'aligne, néanmoins, avec son sous-titre plutôt du côté de Nietzsche » 
(1993), a tradução pode, no seu fazer, criticar os imperialismos e propor o que chama de "tradução democrática" (SPIVAK, 2005, p. 16) para fortalecer relações horizontais, verdadeiramente recíprocas entre as culturas. Contra o imperialismo, ela propõe uma reflexão ética sobre a particularidade das formas culturais atenta à alteridade radical do outro, ou seja, um modelo de tradução desfamiliarizante, que expõe os limites da linguagem. A tradução é um relacionar-se, "esse relacionar-se com o outro como fonte da própria elocução é o ético como ser relacional, como um ser-para." (SPIVAK, 2005, p. 58, grifo nosso).

A relação ética do ponto de vista do anfitrião, como a que Berman (1984) propõe, deve não só oferecer um abrigo (na língua), mas um ouvir, como nos propõe Spivak (2005, p.58, grifos nossos): "Mas a tradução fundadora entre as pessoas é um ouvir atentamente, com afeto e paciência, a partir da normalidade do outro, o suficiente para perceber que o outro, silenciosamente, já fez esse esforço". Um ouvir que permite, de fato, a abertura ao outro enquanto outro, para ouvir o que diz e como o diz, e não o que convém para nossa língua, para nossas convenções sociais, que ele diga. Admitindo as diferenças, não posso dizer o que ele diz sem uma transformação da língua que traduz; só se traduz o diferente diferentemente. Ou ainda como diz Eduardo Viveiros de Castro (2018), se alinhando a Pannwitz, citado por Walter Benjamin em "A tarefa do tradutor": "Uma boa tradução é uma que permite que os conceitos alienígenas deformem e subvertam a caixa de ferramentas conceitual do tradutor para que o intentio da língua original possa ser expresso dentro da língua nova" (2018, p. 250).

Quando se discute a relação ética nos estudos da tradução, é preciso constatar que, de fato, se discute a relação ética do anfitrião, ou seja, a discussão recai sobre o traduzir, e não sobre o traduzir-se. Visando problematizar a relação ética no traduzir-se, propomos antes diferenciar as noções de estrangeiro e de e/i-migrante, e delimitar (mesmo que provisoriamente) as categorias de tradução e versão.

\section{A prova do e/i-migrante}

Se a Prova do estrangeiro (1984) foi uma virada ética nos estudos da tradução, o movimento do traduzir-se convoca o paradigma da e/ imigração, o ponto de vista do sujeito migrante em busca de um território para viver. Assim, propomos discutir as próprias noções de estrangeiro e migrante para problematizar o que seria uma prova do e/i-migrante. 
Nadia Yala Kisukidi (2017) nos lembra que a categoria "estrangeiro" deve ser apreendida, sobretudo, política e juridicamente. $\mathrm{O}$ estrangeiro se define politicamente na sua relação com a soberania de um estado, a qual produz elementos jurídicos que dizem o que é nacional e o que não é. Assim, o estrangeiro é sempre definido negativamente como aquele que não é nacional e é visto como inimigo porque ameaça a coesão nacional. Além disso, há uma diferença quase ontológica entre eles; todo imigrante é um estrangeiro (mesmo depois de conseguir juridicamente seu registro nacional), no entanto, nem todo estrangeiro é um imigrante. $\mathrm{O}$ estrangeiro que vê e lê de fora pode proporcionar um descentramento do local, mas não chega a transformar o tecido social e cultural (além de questionar os princípios filosóficos e religiosos) ao ponto de se falar em revitalização como o faz a imigração. Para Alexis Nouss (2020, p. 240, tradução nossa),

O estrangeiro conforta a ordem estabelecida pela racionalidade espacial. Ele representa o fora ou o alhures sem os quais o aqui ou o dentro não encontram legitimidade. Ele não perturba; pelo contrário, ele participa do arranjo social - seu sotaque esclarece $o$ falar-bem e a cor da sua pele dá destaque à do autóctone. ${ }^{12}$

Se os estrangeiros podem manter uma "autonomia psíquica e intelectual" que os protege quando se expõem ao mundo, o migrante e o exilado estão sempre num duplo vínculo emocional e reflexivo. Segundo Nouss (2020, p. 241, tradução nossa): “(...) a identidade exílica se funda numa crise permanente que diz respeito ao conjunto dos valores e dos critérios de julgamento e que obriga o exilado a uma postura crítica ininterrupta" ${ }^{13} \mathrm{O}$ exílio e a migração reproduzem esse estado de crise/ crítica/ruptura na medida em que suas experiências só escancaram a divisão entre dois pertencimentos e a separação desses dois lugares. Pois, como diz ainda Nouss (2020, p. 241, tradução nossa), "o estrangeiro se repete ele-mesmo, mas em outro ambiente, outra língua, enquanto,

\footnotetext{
${ }_{12}$ «L'étranger conforte l'ordre établi par la rationalité spatiale. Il représente le dehors ou l'ailleurs sans quoi l'ici ou le dedans ne trouvent pas leur légitimité. Il ne dérange pas ; au contraire, il participe de l'arrangement du social - son accent éclaire le bienparler et la couleur de sa peau fait ressortir celle de l'autochtone. »

${ }_{13}$ « (...) l'identité exilique prend sa source dans une crise permanente qui touche à l'ensemble des valeurs et des critères de jugement et qui oblige l'exilé à une posture critique ininterrompue. »
} 
o exilado não consegue fazê-lo. Reprodução impossível que obriga o exilado à tradução". ${ }^{14}$

$\mathrm{O}$ e/i-migrante está em tradução permanente, ele se instala e ao dividir a língua e o território, não podendo se reproduzir, produz território e língua. Transforma o que poderia ser chamado de identidade nacional por se confrontar diretamente com ela, pois não se contenta/aceita ser colocada/arquivada em qualquer prateleira de uma estante de literatura estrangeira, está aqui para se confrontar e mudar a literatura dita nacional.

O migrante é, ao mesmo tempo e não sucessivamente, um ex/in, pois nunca deixa de ser os dois e reivindica as duas territorialidades para inventar outras num processo crítico-criativo (digestivo). A figura do e/imigrante convoca diferentes sistemas referenciais, dois no mínimo, entre o lugar de partida e o lugar de chegada, a pessoa e o grupo, o estrangeiro e o nacional. No entanto, a experiência da e/imigração nem sempre separa o que a distância afastou, e esse pensamento dual que perpassa a lógica cidadã dos estados-nações não consegue integrar a complexidade do fenômeno da e/imigração impossibilitando o pensar outros modelos éticos-políticos a partir dessa experiência.

A prova do e/i-migrante pede uma permanência, uma relação transformadora, de si, do outro, e do tecido sociocultural (sistema cultural). Traduzir-se (e traduzir) no/pelo outro, não só para pass(e)ar, mas para residir, se relacionar e (se) transformar (confrontando-se). Essa prova passa pelo reconhecimento po-ético da relação como "uma dimensão essencial no devir das sociedades e das línguas, e não somente um efeito ou uma consequência" (GLISSANT, 1990 p. 188). E, como diz Nouss, é preciso pensar a migração contemporânea enquanto processo constituinte de uma sociedade democrática: "A migração é um componente da democracia contemporânea na Europa e enquanto não for considerada como tal, ela persistirá em se apresentar como uma "crise"15 (2020, p. 251, tradução nossa). A migração, como a tradução, não são efeitos e consequências (que são da ordem da explicação), mas processos

\footnotetext{
${ }^{14}$ «L'étranger se répète lui-même mais dans un autre environnement, une autre langue tandis que l'exilé n'y parvient pas. Reproduction impossible qui oblige l'exilé à la traduction .»

${ }^{15}$ « La migration est une composante de la démocratie contemporaine en Europe et tant qu'elle ne sera pas considérée comme telle, elle persistera à se présenter comme une 'crise'. »
} 
relacionais transformadores (da ordem do comentário e da crítica). A migração nos compõe interior e exteriormente. Entre pensar uma língua que tudo traduz com olhar neocolonialista e a intraduzibilidade das especificidades, temos corpos em relação que garantem um movimento crítico-inventivo dos sujeitos e das línguas.

Essa perspectiva de línguas em relação, sua diversidade e seu potencial crítico-inventivo modifica, como ressalta Arnold Castelain (2020, p.21, tradução nossa), o sentido da multiplicidade e a interação entre migrantes e país de chegada:

Longe de ser um acidente contingente vindo de fora contra o qual teria de se proteger, na realidade, elas vêm traduzir algo das sociedades anfitriãs. A multiplicidade nos confronta com nada menos que a fragmentação estrutural do falar humano, sua diversidade. Enquanto uma cultura estiver viva, ela é capaz de se expor a ela, de encontrar nela uma fonte de renovação. Eis onde nos conduz um pensamento da tradução e uma ética fundada na alteridade, tradução e encontro, na encruzilhada do histórico e do político. $^{16}$

Não nos traduzimos pelo/no outro apenas para pass(e)ar, mas para nos relacionar com o autóctone. Nos traduzimos porque temos algo a dizer? Ou por reconhecimento? Que relação ética se estabelece nesses diferentes comportamentos? Nos traduzimos porque queremos ser ouvidos e porque precisamos participar ativamente (sem subalternidade) do debate/diálogo mundial (pelo menos para deslocá-lo). Assim, podemos nos perguntar: que tipo de distinção/diferença de comportamento ético construímos entre traduzir e traduzir-se, entre tradução e versão, nas coordenadas histórico-geopolíticas atuais? Não pretendemos responder a tal pergunta (no mínimo pretensiosa), mas iniciá-la e provocar a discussão.

\footnotetext{
${ }^{16}$ « Loin d'être un accident contingent venant d'un dehors contre lequel il s'agirait de se prémunir, en réalité elles [les langues] viennent traduire quelque chose des sociétés d'accueil. La multiplicité ne nous confronte avec rien de moins que l'éclatement structural du parler humain, sa diversité. Tant qu'une culture est vivante, elle est capable de $s^{\prime} y$ exposer, d'y trouver une source de renouvellement ${ }^{15}$. Voilà où nous mènent une pensée de la traduction et une éthique fondée sur l'altérité, la traduction et la rencontre, à la croisée de l'historique et du politique. »
} 


\section{Direcionalidades e afetividades}

Se o conceito de tradução, para se tornar comum (ao identificar uma área), deve ser reduzido à passagem de um texto em uma língua para um texto em outra língua, essa redução não significa que o conceito deixe de ser problematizado, polemizado, criticado, enfim, discutido no âmbito não só da área da tradução, mas em diversas áreas de saber como a antropologia, a literatura comparada, a filosofia. O que traduzimos? Quem traduz? Como traduzimos? Para quem traduzimos? São questões práticas desdobradas nos discursos teóricos-metodológicos e configuram linhas, correntes, escolas, filiações epistemológicas que tornam polissêmico o conceito dentro dos estudos da tradução. Desse modo, os termos tradução e versão são objetos de discussão numa ampla literatura da área. Como nosso propósito se inscreve na pronominalização do traduzir-se e, com isso, nas problemáticas da direcionalidade e da afetividade, usaremos, por questões práticas, os termos da maneira seguinte:

- tradução: toda relação estabelecida entre duas línguas-culturas não importando a fonte e o alvo, nem a relação que o sujeito tradutor trava com essas línguas-culturas. Um texto produzido a partir de uma anterioridade e com a qual tem uma relação interdiscursiva explícita.

- tradução stricto senso: a relação estabelecida entre duas línguasculturas em que a fonte é um de fora e o alvo um dentro, e em que a relação do sujeito tradutor com essas línguas é afetivamente diferente. ${ }^{17}$

- Versão: a relação estabelecida entre duas línguas-culturas em que a fonte é um dentro e o alvo um fora, e em que a relação do sujeito tradutor com essas línguas é afetivamente diferente.

Como podemos perceber, a relação afetiva que o sujeito tradutor trava com as línguas que ele traduz influi sobre as categorias de tradução stricto senso e versão. Desse modo, os próprios conceitos de língua materna e língua estrangeira devem ser problematizados já que, ao nosso ver, não podemos falar de língua estrangeira para o sujeito-tradutor, caso contrário ele não traduziria, seria um mero leitor de traduções. Como

${ }^{17} \mathrm{O}$ sujeito não é afetado e não afeta, do mesmo modo, as línguas que fala. 
a categoria estrangeiro, o conceito de língua estrangeira mobiliza um discurso de estados-nações; no entanto, pode até ser estrangeiro à nação, mas não ao tradutor. Além disso, o conceito de língua materna ${ }^{18}$ já foi bastante problematizado nas pesquisas sobre migrações e nos discursos da psicanálise (língua má-terna). As coordenadas espaço-temporais e sociais do sujeito-tradutor são fundamentais na delimitação dessas categorias para entender a relação afetiva que ele trava com as línguas que ele traduz e influencia a própria noção de direcionalidade no processo tradutório. Pois, para poder falar de um dentro e um fora, de um mesmo e um outro, temos que perguntar: dentro e fora de quê? Mesmo e outro de quem? Quais as coordenadas linguísticas e territoriais do texto e do tradutor?

Discutimos a relação ética estabelecida entre duas línguas-culturas em que a fonte é um dentro (ex-, a partida) e o alvo é um fora (in-, a chegada). Há um deslocamento do texto que sai do seu local/língua de produção e vai (tentar) se instalar em outro local/língua através da versão. Há um duplo movimento de emigração/imigração, de sair de si em direção ao outro no qual não pretende só se hospedar, mas se instalar. Uma relação em que o sujeito-tradutor tem mais familiaridade (não em termos de conhecimento, mas de afecção) com a língua fonte do que com a língua alvo onde ele instaura o outro.

\section{O outro é a chegada que me torna outro}

A visada ética, para Berman (1984), é, como vimos, uma relação de respeito com o original e com a alteridade, dois termos que se confundem, já que a alteridade de que fala é sempre o original que traduzo na minha língua. No entanto, traduzir-se no outro separa as noções de

\footnotetext{
${ }^{18} \mathrm{Eu}$, filha de imigrantes portugueses na França, tenho relações afetivas com as duas línguas sem conseguir discernir qual seria minha língua materna. Comecei a falar em português, ao viver na França fui alfabetizada em francês, e o português, por ter sido esquecido, se tornou na adolescência uma língua de herança por ser filha de portugueses e língua estrangeira (porque não era a francesa) aprendida na escola. Ao migrar para o Brasil aos 25 anos, o francês penetrava meu português com seu sotaque e depois de 25 anos no Brasil comecei a ter sotaque brasileiro em francês, sem nunca ter deixado de ter um sotaque francês no português. O que quero dizer é que essas categorias não são fixas: de língua materna, o português passou a ser língua de herança e língua segunda acadêmica, e hoje é a língua veicular de uso cotidiano; o francês de língua de alfabetização virou língua madrasta e mais tarde língua de pesquisa.
} 
original e de alteridade, já que quem "hospeda" é o outro. Não estamos mais em posição de anfitrião. Como traduzir numa dupla relação ética com a alteridade e com o original que dessa vez não estão do mesmo lado? Ou seja, como (porque é sempre um modo de) ser ético comigo mesmo e com o outro? A relação ética parece sempre problematizada unidirecionalmente, ou seja, eu com o outro, e não na dupla relação, eu com eu e eu com o outro. Meschonnic (2007, p. 19) a esse respeito define a relação ética como um comportamento em relação a mim-mesmo e ao outro, em suas palavras: "A ética, questão de comportamento. Consigo e com os outros. A ética, é o que fazemos de si, e dos outros. É um agir, e é dar valor". ${ }^{19}$

No traduzir-se em/com o outro, a noção de alteridade se complexifica: saio de mim para a alteridade, e ao fazê-lo, me torno a alteridade da alteridade, ou seja, não me torno o outro (nunca o serei), mas o outro do meu outro num movimento de volta a mim.

É bom lembrar que uma certa tradição ética nos conduz mais a fazer tradução do que versão, sobretudo, no que diz respeito à literatura. Parece, a princípio, mais ético traduzir o outro em mim, acolhê-lo, do que ir ocupar espaço no outro. É mais fácil pensar a relação ética do anfitrião, sobretudo para os países hegemônicos, do que imaginar a e/imigração como comportamento político (po-ético). A prova do estrangeiro põe à prova o anfitrião, eticamente condescendente e tolerante. A voz é de quem recebe e não de quem chega: estando em território estrangeiro (que não é dele), o imigrante parece perder a autoridade/legitimidade para falar e agir. Ora, "a questão do estrangeiro", como diz Derrida, "é a questão do estrangeiro, (...) aquele que ao questionar primeiro, me põe em questão" (1997, p. 11, grifo do autor). ${ }^{20}$

No processo de globalização do conhecimento e de mercadorias, como aliás no movimento de migrações, cada vez mais, temos que nos traduzir para o outro. A corrida à internacionalização das universidades, por exemplo, a divulgação das pesquisas desenvolvidas nos faz, cada vez mais, recorrer à versão. Até ao escrever diretamente em outra língua, um processo de versão nos mobiliza, sobretudo porque falamos de nós,

\footnotetext{
${ }^{19}$ «L'éthique, question de comportement. Avec soi et avec les autres. L'éthique, c'est ce qu'on fait de soi, et des autres. C'est un agir, et c'est faire de la valeur. » ${ }^{20}$ « (...) la question de l'étranger est une question de l'étranger. (...) celui qui posant la première question, me met en question. »
} 
de nossas pesquisas, para o outro, numa outra língua. Cabe então se perguntar como nos traduzimos no outro? Que relação estabelecemos com o outro autóctone que nos torna o outro?

De maneira geral, a versão é confiada aos ditos nativos de lá por ter uma relação afetiva, mesmo que distante, com a chegada e a partida: de quem vive aqui (imigrante) e saiu de lá (emigrante). Talvez, nesse sujeito, tradução e versão se embaralhem/mesclem. Assim, parece que se traduzir para outra língua é tarefa do outro, ou melhor do e/i-migrante. Mas a versão também é tarefa de nativos daqui (diferente dos nativos de lá), que alimentam uma relação afetiva com a língua e a cultura de lá, por já terem morado lá, ou seja, por terem sido imigrantes e/ou estrangeiros lá, por serem especialistas e/ou amantes da língua e da literatura de lá...

A questão ética na versão parece, desde já, recair, por um lado, no sujeito tradutor: quem faz versão? E que tipo de relação tem com a outra língua (a outra do texto, não obrigatoriamente outra para ele)? $\mathrm{E}$, por outro, nas relações de poder que se instauraram historicamente entre as línguas: em que línguas nos traduzimos e como nos traduzimos em função de que língua? Enfim, que comportamento ético, na relação consigo e com o outro, pode, no processo de versão, reiterar poderes hegemônicos ou quebrar assimetrias históricas? Pois, como a grande maioria das migrações no período pós-colonial, os movimentos tendem a ir para os países hegemônicos para "ganhar valor". Claro que também existem migrações contrárias, mas estas custam a se assumir e/i-migrantes e preferem a figura do estrangeiro e/ou do ex-patriado. E ainda, nessa mesma direção (países hegemônicos $\rightarrow$ países do "terceiro mundo"), as e/i-migrações imperialistas que se traduziram no outro para melhor impor sua lógica e submeter o autóctone.

No migrante, a dupla relação e/i- tensiona seu agir. A relação com a partida é uma relação com nós mesmos e a vontade (ou necessidade) de sair. Vários afetos se desenham aí, sem dúvida, como o valor de ser publicado numa língua de prestígio, por exemplo. Questões como: para que língua decidimos e/i-migrar? Por quem queremos ser lidos e quem queremos afetar? Há línguas que nos afetam mais ou nas quais queremos mais nos transformar? Que internacionalização queremos? Na atual conjuntura, sabemos que existem línguas que nos internacionalizam mais que outras, ou pelo menos que não propõem a mesma globalização. 


\section{Considerações finais}

Propor pensar um comportamento ético a partir da figura do e/imigrante se deu por querer pensá-lo na dupla vinculação com o lugar de partida e o de chegada. Essa dupla relação ética permite também sair da oposição tão criticada, mas ainda tão tradicional, entre os fontistas e os alvistas, pois, na versão, essa separação teórica não procede. Pensar o traduzir-se eticamente apenas a partir da relação com a alteridade corre o risco de cair na condescendência ou ainda na tolerância (noção tão cara aos discursos antirracistas dos anos 80), como se tolerar fosse reconhecer. $\mathrm{Na}$ versão, como vimos, alteridade e original não se confundem, e o traduzir-se eticamente relaciona-se com ambos.

Em relação a nós mesmos, ao original no caso, cabe-nos, a "pura visada ética" à la Berman, um traduzir que não incorra em "in-verdades", mas, também nos cabe a garantia de um não apagamento poético, de não se submeter ao ponto de se (des)integrar no/pelo/com o outro, nos cabe chegar como outro do outro (porque sempre seremos) numa volta a si. Enfim, também nos cabe não impor nossos próprios valores como sendo absolutos, universais e não nossos. Em relação à alteridade, à chegada, cabe nos instalar (não só pass(e)ar) para afecções e transformações. Afinal, ao querer/ter que se traduzir no outro, estamos levando uma diferença para confrontá-la com a da alteridade, num movimento de diálogo e de reciprocidade horizontal, reconhecendo as assimetrias das relações de poder para não as reiterar. $\mathrm{O}$ exercício de se escrever em outra língua, nos afeta ao nos fazer perceber nossas diferenças (às quais nos tornamos indiferentes) e ao nos desestabilizar/desterritorializar nos abre ao devir po-ético. Um exercício de humor, de ironia e de espanto.

Das questões levantadas, várias interrogam tanto a tradução stricto sensu quanto versão. Ensaiamos um pensar político e poético sobre a relação ética do movimento reflexivo (pronominalização). Longe de ser uma tentativa epistemológica ou teológica de delimitar um traduzir-se ético, discutimos, antes de tudo, um agir po-ético na relação de corpos localizados geopolítica e historicamente. A relação tem direção e a letra tem corpo(s). 


\section{Referências}

BERMAN, Antoine. L'Épreuve de estranger: culture et traduction dans l'Allemagne romantique. Paris: Gallimard, 1984.

BERMAN, A. A tradução e a letra ou o albergue do longínquo. Trad. Marie-Hélène Catherine Torres, Mauri Furlan, Andreia Guerini. Rio de Janeiro: 7 Letras, 2007.

BERMAN, Antoine. Pour une critique des traductions: John Donne. Paris: Gallimard, 1995.

CASTELAIN, Arnold. Introduction à l'ouvrage. In: (dir.). Traduction et migration: Enjeux éthiques et techniques. Paris: Presses de l'Inalco, 2020. DOI: https://doi.org/10.4000/books.pressesinalco.35734 DERRIDA, Jacques. Anne Dufourmantelle invite Jacques Derrida à répondre De l'hospitalité. Paris: Calmann-Levy, 1997.

GLISSANT, Édouard. Poétique de la relation. Poétique III. Paris: Gallimard, 1990.

GODARD, Barbara. L'Éthique du traduire: Antoine Berman et le « virage éthique » en traduction. TTR, Ottawa, v. 14, n. 2, p. 49-82, 2001. DOI: https://doi.org/10.7202/000569ar

KISUKIDI, Nadia Yala. Que fait-on de l'étranger aujourd'hui?, Seminário da Journée d'étude de la Chaire «Exil et migrations», 2017. Disponível em: https://www.canal-u.tv/video/fmsh/que fait_on de_1_etranger_aujourd_hui_nadia_yala_kisukidi.44953. Acesso em: $04 \overline{/ 0} \overline{9} / 2019$.

MESCHONNIC, Henri. Poétique du traduire. Paris: Verdier, 1999.

MESCHONNIC, Henri. Éthique et politique du traduire. Paris: Verdier, 2007.

NOUSS, Alexis. Le mensonge du migrant: un défit éthique. In: CASTELAIN, Arnold (dir.). Traduction et migration : Enjeux éthiques et techniques. Paris: Presses de l'Inalco, 2020. DOI: https://doi.org/10.4000/ books.pressesinalco.36204

PYM, Anthony. Pour une éthique du traducteur. Arras/Ottawa: Artois Presses Université/Presses de l'Université d'Ottawa, 1997. 
SAMOYAULT, Tiphaine. Langues en lutte: limites des éthiques de la traduction. In: CASTELAIN, Arnold (dir.). Traduction et migration: Enjeux éthiques et techniques. Paris: Presses de 1'Inalco, 2020. DOI: https://doi.org/10.4000/books.pressesinalco.36147

SPIVAK, Gayatri Chakravorty. Tradução como cultura. Tradução de Eliana Ávila e Liane Schneider. Ilha do Desterro, Florianópolis, n. 48, p. 41-64, 2005. DOI: https://doi.org/10.5007/\%25x. Disponível em: https://periodicos.ufsc.br/index.php/desterro/article/view/9833. Acesso em: 13 mar. 2020.

SPIVAK, Gayatri Chakravorty. The Politics of Translation. In:

Outside the Teaching Machine. New York: Routledge, 1993. p. $\overline{200-225}$.

VENUTI, Lawrence. The Scandals of Translation: Towards an Ethics of Difference. New York: Routledge, 1998. DOI: https://doi. org/10.4324/9780203269701

VIVEIROS DE CASTRO, Eduardo. A antropologia perspectivista e o método da equivocação controlada. Tradução de Marcelo Giacomazzi Camargo e Rodrigo Amaro. Aceno - Revista de Antropologia do CentroOeste, Cuiabá, v. 5, n. 10, p. 247-264, 2018.

WITTGENSTEIN, Ludwig. Tractatus Logico-philosophicus. Tradução de Luiz Henrique Lopes do Santos. São Paulo: EdUSP, 1994.

ZAIDAN, Junia; BAKER, Mona. Tradução e transformação social: uma entrevista com Mona Baker. Percursos Linguísticos, Vitória, v. 9, n. 21, p. 14-35, 2019. Disponível em: https://periodicos.ufes.br/percursos/ article/view/27272. Acesso em: 12 mar. 2020.

Recebido em: 25 de abril de 2020. Aprovado em: 28 de setembro de 2020. 